\title{
Biomarker similarities between the saline lacustrine Eocene Green River and the Paleoproterozoic Barney \\ Creek Formations
}

FrenCH, K.L. ${ }^{1}$, BiRdwEll, J.E. ${ }^{1}$, VANDEN BERG, M.D. ${ }^{2}$

${ }^{1}$ U.S. Geological Survey, Central Energy Resources Science Center, Denver, CO 80225

${ }^{2}$ Utah Geological Survey, Energy and Mineral Program, Salt Lake City, UT 84116

The Paleoproterozoic Barney Creek Formation (BCF) is currently interpreted to have been deposited in a restricted, deep marine paleoenvironment. The BCF plays a disproportionate role in our understanding of Proterozoic ocean chemistry and the rise of complex life due to limited sedimentary archives of similar age and remarkable thermal preservation. Several unusual biomarker features have been identified in the BCF, specifically its methylhopane and carotenoid signatures. We demonstrate that the saline lacustrine Eocene Green River Formation shares a similar distribution of methylhopanes and carotenoids. This methylhopane and carotenoid pattern is observed in other saline lacustrine organic matter, but this biomarker assemblage as a whole is not observed in marine organic matter of any geologic age. Our results imply a saline lacustrine depositional environment for the BCF, which agrees with earlier but now abandoned depositional models of this formation. In light of a revised depositional environment, models of Proterozoic ocean chemistry and emergence of complex life that rely on a marine Barney Creek Formation should be reevaluated. Alternatively, if Paleoproterozoic marine biomarker signatures resemble those of younger saline lacustrine systems, then this must be recognized to accurately interpret geologic biomarker and paleoenvironmental records. 